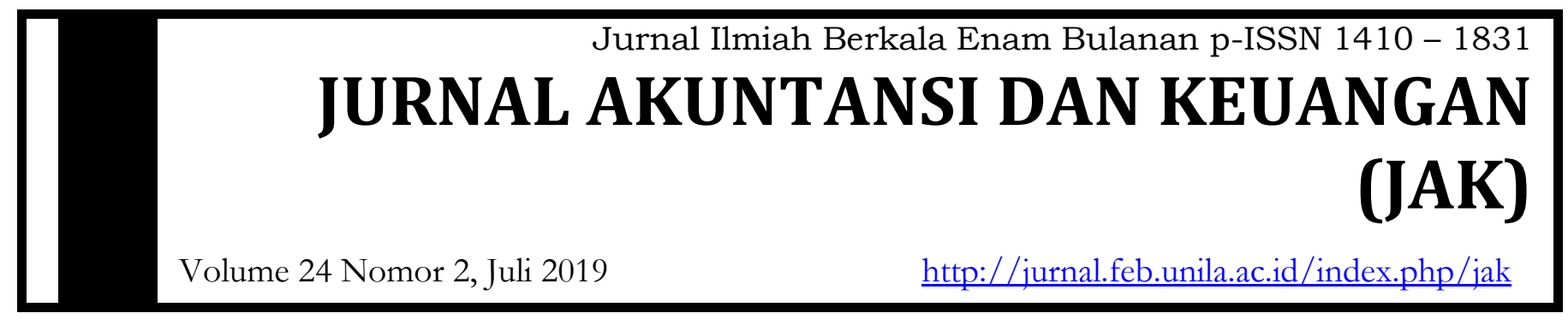

\title{
PENGARUH KINERJA KEUANGAN PEMERINTAH DAERAH TERHADAP PERTUMBUHAN EKONOMI (STUDI PADA DAERAH PEMEKARAN DI PULAU SUMATERA)
}

\author{
Reza Rinova ${ }^{1}$, Fajar Gustiawaty Dewi ${ }^{2}$ \\ ${ }^{1}$ Fakultas Ekonomi dan Bisnis Universitas Lampung \\ ${ }^{2}$ Fakultas Ekonomi dan Bisnis Universitas Lampung
}

\section{Informasi Naskah}

Update Naskah:

Dikumpulkan: 30 Mei 2019;

Diterima: 30 Juni 2019;

Terbit/Dicetak: 30 Juli 2019

\section{Keywords:}

Ratio of Decentralization Degree, Regional Dependency Ratio, LGR Effectiveness Ratio, Economic Growth, and Expansion Area.

\begin{abstract}
$\underline{\text { Abstract }}$
Expansion of regions is aimed to prosper the community. In 2018 as many as 314 proposals for expansions could not be approved by the Minister of Home Affairs because the impact was not in line with expectations. This study aims to see the direct effect of the financial performance of the newly formed government regions on economic growth. Expansion area are divided into two forms, namely the old expansion area and the new expansion area. The financial performance of the local government is measured using the ratio of decentralization rates, regional dependency ratios, and the effectiveness of LGR (Locally-Generated Revenue) ratios. Population in this study is all the expansion areas of districts/cities on the island of Sumatera. Time-series secondary data year 2013-2017 covering regional original income, total regional income, transfer income, regional original income budget, and realization of Gross Regional Domestic Product (GRDP) were used. Using SPSS tool, the results shows that the ratio of the degree of decentralization has a negative effect on economic growth. Furthermore, regional dependency ratios do not affect economic growth. The LGR effectiveness ratio has a positive effect on economic growth.
\end{abstract}




\section{A. PENDAHULUAN}

Tanggungjawab sebagai daerah otonomi adalah dalam hal pembangunan dan perkembangan yang merujuk pada kesejahteraan rakyat di masing-masing daerah tersebut. Pemberian kewenangan dan tanggungjawab untuk daerah otonom telah diatur dalam UU No 32 Tahun 2004 tentang Pemerintah Daerah yang mengurus sendiri urusan pemerintahan dan kepentingan masyarakat setempat sesuai dengan peraturan perundang-undangan yang berlaku. Tentunya, mengurus kepentingan tersebut dilakukan agar masyarakat lebih sejahtera. Kesejahteraan tersebut dapat dilihat dari tingkat pendidikan, kesehatan, pengangguran, pelayanan publik, dan tingkat pertumbuhan ekonomi.

Penyelenggaraan otonomi daerah sendiri nantinya akan mewujudkan tujuan utama desentralisasi. Salah satu tujuan utama desentralisasi adalah demi terwujudnya kesejahteraan masyarakat. Dalam hal ini, diharapkan tidak adanya kesenjangan diberbagai daerah. Karena masih banyak ditemukan tidak meratanya kesejahteraan di berbagai daerah sehingga mendorong terjadinya pemekaran daerah. Pemekaran daerah berdasarkan undang-undang No. 23 tahun 2014 yaitu pemecahan daerah provinsi atau daerah kabupaten/kota untuk menjadi dua atau lebih daerah baru atau penggabungan bagian daerah dari daerah yang bersanding dalam satu daerah provinsi menjadi satu daerah baru. Pemerintah daerah baru ini pun diharapkan memiliki kinerja keuangan yang baik sehingga terjadi percepatan pertumbuhan ekonomi dan pemerataan kesejahteraan. Penggunaan indikator kinerja sangat penting untuk mengetahui apakah suatu program kerja telah dilaksanakan secara efisien dan efektif (Mardiasmo (2002).

Pada penelitian ini, tiga indikator yang akan digunakan adalah rasio derajat desentralisasi, rasio ketergantungan daerah, dan rasio efektivitas. Nantinya, kinerja keuangan pemerintah daerah ini diharapkan akan menggambarkan sejauh mana kinerja pemerintah daerah dalam upaya peningkatan pertumbuhan ekonomi. Karena, tercapainya pertumbuhan ekonomi yang tinggi serta menurunnya pengangguran dan kemiskinan juga tidak terlepas dari pengelolaan keuangan daerah yang baik (Berliani, 2016). Terlebih, bagi kabupaten/kota hasil pemekaran. Dibawah ini tabel daerah pemekaran di Pulau Sumatera.

Tabel 1 Daerah Pemekaran di Pulau Sumatera

\begin{tabular}{ccc}
\hline NO & Provinsi & Jumlah Daerah Pemekaran \\
\hline \hline 1 & Aceh & 13 \\
2 & Sumatera Utara & 16 \\
3 & Sumatera Barat & 5 \\
4 & Sumatera Selatan & 9 \\
5 & Bengkulu & 6 \\
6 & Lampung & 10 \\
7 & Jambi & 5 \\
8 & Riau & 7 \\
9 & Kepulauan Riau & 6 \\
10 & Bangka Belitung & 4 \\
\hline Total & $\mathbf{1 0}$ & $\mathbf{8 1}$ \\
\hline \hline
\end{tabular}

Berita terbaru yang dikutip dari www.kupastuntas.co yaitu usulan pembentukan daerah otonomi baru bagi Kabupaten Lampung Tengah yaitu Kabupaten Seputih Barat dan Kabupaten Seputih Timur. Namun, Menteri Dalam Negeri Tjahjo Kumolo menyampaikan bahwa sebanyak 314 usulan pemekaran daerah untuk saat ini tidak dapat disetujui. Karena, ternyata dampak pemekaran kurang sesuai dengan harapan (dikutip dari (www.nasional.tempo.co).

Pada penelitian sebelumnya oleh Astuti (2015) dan Berliani (2016) memuat kesimpulan bahwa rasio efektivitas sebagai kinerja keuangan daerah memiliki pengaruh positif terhadap pertumbuhan ekonomi. Dalam penelitiannya Rosdyana, dkk. (2015) menyimpulkan bahwa pengaruh desentralisasi fiskal 
yang diukur melalui rasio derajat desentralisasi secara simultan berpengaruh positif terhadap pertumbuhan ekonomi. Namun, penelitian yang dilakukan oleh Pradiatmi, dkk. (2017) menyatakan bahwa rasio efektivitas tidak berpengaruh terhadap pertumbuhan ekonomi. Pada penelitian yang dilakukan oleh Prihastuti, dkk. (2015) menyatakan bahwa rasio ketergantungan daerah berpengaruh positif signifikan terhadap pertumbuhan ekonomi. Namun, Sari, dkk. (2016) menyatakan bahwa rasio ketergantungan daerah berpengaruh negatif terhadap pertumbuhan ekonomi. Penelitian ini bertujuan untuk menganalisis pengaruh kinerja keuangan pemerintah daerah terhadap pertumbuhan ekonomi di Pulau Sumatera pada periode waktu dari tahun 2013 hingga tahun 2017.

\section{B. LANDASAN TEORI DAN PENGEMBANGAN HIPOTESIS}

Indikator kemajuan suatu daerah dapat diukur, salah satunya dengan melihat pertumbuhan ekonomi. Pertumbuhan ekonomi dapat diartikan sebagai perkembangan kegiatan dalam perekonomian yang menyebabkan barang dan jasa yang diproduksi dalam masyarakat bertambah dan kemakmuran masyarakat meningkat. Pertumbuhan ekonomi dapat juga diartikan sebagai kenaikan Gross Domestic Product (GDP) atau Gross National Product (GNP) tanpa memandang apakah kenaikan itu lebih besar atau lebih kecil dari tingkat pertumbuhan penduduk atau apakah perubahan struktur ekonomi terjadi atau tidak (Arsyad, 1999). Pertumbuhan ekonomi menunjukkan sejauh mana aktivitas perekonomian akan menghasilkan tambahan pendapatan masyarakat pada suatu periode tertentu. Perekonomian dianggap mengalami pertumbuhan apabila seluruh balas jasa riil terhadap penggunaan faktor-faktor produksi pada tahun tertentu lebih besar daripada pendapatan riil masyarakat pada tahun sebelumnya (Berliani, 2016).

Pengertian Produk Domestik Regional Bruto menurut Badan Pusat Statistik (2004) yaitu jumlah nilai tambah yang dihasilkan untuk seluruh wilayah usaha dalam suatu wilayah atau merupakan jumlah seluruh nilai barang dan jasa akhir yang dihasilkan seluruh unit ekonomi di suatu wilayah. PDRB dapat dijadikan sebagai indikator laju pertumbuhan ekonomi sektoral agar dapat diketahui sektor-sektor mana saja yang menyebabkan perubahan pada pertumbuan ekonomi. Kuncoro (2014) menuliskan dalam bukunya yang berjudul "Otonomi Daerah" bahwa ada dua cara untuk menghitung pertumbuhan ekonomi berdasarkan PDRB. Yaitu, PDRB riil (harga konstan) dan nominal (harga berlaku). Namun pertumbuhan ekonomi yang dihitung berdasarkan PDRB riil (harga konstan) akan memberikan gambaran pertumbuhan output secara nyata karena PDRB riil telah memasukkan faktor inflasi.

Pertumbuhan ekonomi ini akan diukur melalui rumus dibawah ini :

$$
\text { Pertumbuhan Ekonomi }=\frac{\text { PDRBt }- \text { PDRBt }-1}{\text { PDRBt }-1} \mathrm{X} 100 \%
$$

\section{Kinerja Keuangan Daerah}

Wachid (2014) "Pengelolaan keuangan daerah yaitu keseluruhan kegiatan yang meliputi perencanaan, pelaksanaan, penatausahaan, pelaporan, pertanggungjawaban dan pengawasan keuangan daerah". Kinerja keuangan pemerintah daerah ini dinilai apakah sesuai dengan target. Salah satu alat untuk menganalisis kinerja Pemda dalam mengelola keuangan daerahnya adalah dengan melakukan analisis rasio keuangan terhadap APBD yang telah di tetapkan dan dilaksanakannya. Analisis rasio keuangan pada APBD dilakukan dengan membandingkan hasil yang dicapai dari satu periode dengan periode sebelumnya, sehingga dapat diketahui bagaimana kecenderungan yang terjadi (Halim, 2007). Berikut rasio keuangan yang digunakan dalam penelitian ini:

\section{Rasio Derajat Desentralisasi}

Semakin tinggi kontribusi PAD maka semakin tinggi kemampuan daerah tersebut dalam penyelenggaraan desentralisasi. Rasio derajat desentralisasi, khususnya komponen PAD dibandingkan dengan TPD (Total Penerimaan Daerah). Menurut hasil penemuan Tim Fisipol UGM menggunakan skala interval sebagaimana yang terlihat dalam tabel berikut: 
Tabel 2 Skala Interval Derajat Desentralisasi

\begin{tabular}{cc}
\hline PAD/TPD $(\boldsymbol{\%})$ & Kemampuan Keuangan Daerah \\
\hline \hline$<10.00$ & Sangat kurang \\
$10.01-20.00$ & Kurang \\
$20.01-30.00$ & Cukup \\
$30.01-40.00$ & Sedang \\
$40.01-50.00$ & Baik \\
$>50.00$ & Sangat baik \\
\hline \hline
\end{tabular}

Sumber : Tim Litbang Depdegri-Tim Fisipol UGM, 1991

Rasio ini dirumuskan sebagai berikut (Mardiasmo (2002):

$$
\text { Derajat desentralisasi }=\frac{\text { Pendapatan Asli Daerah }}{\text { Total Pendapatan Daerah }} \times 100 \%
$$

\section{Rasio Ketergantungan Keuangan Daerah}

Semakin rendah tingkat rasio ketergantungan keuangan suatu daerah, dapat disimpulkan bahwa daerah tersebut semakin mampu atau mandiri dalam hal bantuan yang diberikan pemerintah pusat/provinsi. Berikut tabel skala interval mengenai ketergantungan keuangan daerah:

Tabel 3 Skala Interval Penilaian Ketergantungan Keuangan Daerah

\begin{tabular}{cc}
\hline Pendapatan Transfer / TPD & Ketergantungan Keuangan Daerah \\
\hline \hline $0,00-10,00$ & Sangat rendah \\
$10,01-20,00$ & Rendah \\
$20,01-30,00$ & Sedang \\
$30,01-40,00$ & Cukup \\
$40,01-50,00$ & Tinggi \\
$>50,00$ & Sangat tinggi \\
\hline \hline
\end{tabular}

Sumber : Tim Litbang Depdagri-Fisipol UGM, 1991

Rasio ini dirumuskan sebagai berikut (Mahmudi, 2010):

$$
\text { Ketergantungan Daerah }=\frac{\text { Pendapatan Transfer }}{\text { Total Pendapatan Daerah }} \times 100
$$

\section{Rasio Efektivitas PAD}

Dalam penelitiannya Sularso, dkk. (2011) menyatakan semakin besar realisasi penerimaan PAD maka semakin efektif kinerja pemerintah daerah.

Tabel 4 Kriteria Penilaian Efektivitas PAD

\begin{tabular}{cc}
\hline Prosentasi kinerja keuangan $(\boldsymbol{\%})$ & Kriteria \\
\hline \hline 100 & Sangat efektif \\
100 & Efektif \\
$90-99$ & Cukup efektif \\
$75-89$ & Kurang efektif \\
$<75$ & Tidak efektif \\
\hline \hline
\end{tabular}

Sumber : Mahmudi (2010)

Rasio ini dirumuskan sebagai berikut (Mahmudi, 2010):

$$
\text { Efektivitas PAD }=\frac{\text { Realisasi Penerimaan PAD }}{\text { Anggaran Penerimaan PAD }} \times 100 \%
$$




\section{Kerangka Pemikiran}

Berdasarkan landasan teori dan penelitian sebelumnya serta permasalahan yang dikemukanan maka sebagai acuan untuk merumuskan hipotesis, berikut disajikan kerangka pemikiran teoritis yang dituangkan dalam model penelitian seperti yang ditunjukkan pada gambar berikut :

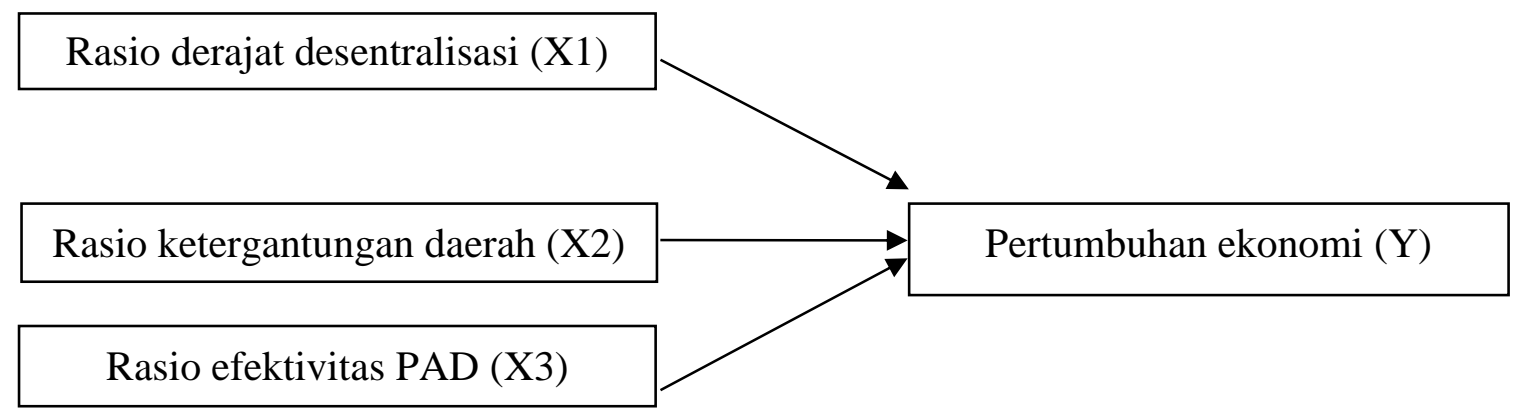

\section{Hipotesis Penelitian}

Berikut hipotesis berdasarkan model penelitian dalam penelitian ini:

\section{Pengaruh Rasio Derajat Desentralisasi Berpengaruh Terhadap Pertumbuhan Ekonomi}

Rasio ini dimaksudkan untuk mengukur tingkat kontribusi PAD sebagai sumber pendapatan yang dikelola sendiri oleh daerah terhadap total penerimaan daerah. Semakin besar kontribusi PAD maka akan semakin baik pula pelaksanaan desentralisasi di daerah otonomi baru tersebut. Rasio ini juga berfungsi untuk melihat sejauh mana penyelenggaraan desentralisasi fiskal telah terjadi di daerah pemekaran. Sularso, dkk. (2011) dalam penelitiannya menyimpulkan bahwa faktor yang mempengaruhi pertumbuhan ekonomi secara tidak langsung dipengaruhi oleh kinerja keuangan daerah salah satunya adalah rasio derajat desentralisasi. Jika dikaitkan dengan teori keagenan dan teori desentralisasi fiskal pemerintah daerah selaku agen diharapkan mampu menggali potensi PAD didaerahnya masing-masing. Namun penelitian yang dilakukan oleh Kharisma (2013) menyatakan bahwa sebelum pelaksanaan desentralisasi selama periode 1995-2000, peran anggaran Pemerintah Daerah dari sisi penerimaan dan pengeluaran terhadap pertumbuhan ekonomi berpengaruh negatif, baik di tingkat nasional, di Jawa maupun luar Jawa. Selanjutnya, daerah pemekaran merupakan daerah yang harus menyelenggarakan desentralisasi dengan baik. Tidak dipungkiri bahwa banyak daerah pemekaran yang terkadang belum siap untuk menerima tanggungjawab untuk mengurus sendiri urusan rumah tangganya. Sehingga masih banyak daerah pemekaran yang belum dapat menyelenggarakan desentralisasi dengan baik. Sehingga hipotesis yang diajukan dalam penelitian ini adalah:

\section{H1: Rasio derajat desentralisasi berpengaruh negatif terhadap pertumbuhan ekonomi daerah hasil pemekaran di Pulau Sumatera.}

\section{Pengaruh Rasio Ketergantungan Keuangan Daerah Terhadap Pertumbuhan Ekonomi}

Rasio ini ini menggambarkan seberapa besar ketergantungan keuangan daerahnya dengan membandingkan antara pendapatan transfer dari pemerintah pusat/provinsi dan total penerimaan daerah. Jadi semakin tinggi angka ini maka semakin tinggi ketergantungan suatu daerah terhadap pemerintah pusat/provinsi. Jika rasio ketergantungan daerah meningkat maka akan menurunkan laju pertumbuhan ekonomi, karena dengan dana transfer yang masih tinggi menyebabkan daerah tersebut memiliki ketergantungan daerah dari pusat untuk mendanai atau membiayai kebutuhan daerahnya sehingga daerah tersebut belum mandiri untuk mengelola keuangannya, sehingga otonomi daerah belum berjalan sesuai dengan semestinya (Sari, dkk., 2016). Dalam penelitiannya Sari, dkk. (2016) menyimpulkan bahwa rasio ketergantungan daerah berpengaruh negatif terhadap pertumbuhan ekonomi. Namun pada penelitian yang dilakukan oleh Prihastuti, dkk. (2015) menyimpulkan bahwa rasio ketergantungan daerah berpengaruh positif terhadap pertumbuhan ekonomi. Jika dikaitkan dengan teori keagenan yang dipakai dalam penelitian ini seharusnya pemerintah daerah sebagai agen dapat mengurangi ketergantungan daerah terhadap pemerintah pusat dalam hal transfer dana. Karena, seharusnya pemerintah daerah mampu atau mandiri dalam hal membiayai dirinya sendiri. Dan, penggunaan dana transfer dapat lebih dioptimalkan untuk memacu pertumbuhan 
ekonomi di daerahnya masing-masing. Namun, karena studi ini dilakukan pada daerah pemekaran yang cenderung masih mendapatkan dana transfer yang besar dari pemerintah pusat/provinsi dan dibutuhkan pengelolaan yang baik bagi pemerintah daerah masing-masing maka besar kemungkinan daerah-daerah pemekaran masih bergantung pada dana yang ditransfer dari pemerintah pusat provinsi. Sehingga hipotesis yang diajukan dalam penelitian ini adalah:

H2: Rasio ketergantungan keuangan daerah berpengaruh negatif terhadap pertumbuhan ekonomi daerah hasil pemekaran di Pulau Sumatera.

\section{Rasio Efektivitas Berpengaruh Positif Terhadap Pertumbuhan Ekonomi}

Pendapatan Asli Daerah (PAD) adalah pendapatan yang terdiri dari pajak daerah, retribusi daerah, hasil pengelolaan kekayaan daerah yang dipisahkan, dan lain-lain PAD yang sah. Ini merupakan salah satu bentuk pengelolaan keuangan oleh pemerintah daerah. Penelitian yang telah dilakukan oleh Zurkarnain, dkk. (2015) menyatakan bahwa rasio efektivitas berpengaruh signifikan terhadap pertumbuhan ekonomi. Penelitian serupa yang dilakukan oleh Sari, dkk. (2015) dan Berliani (2016) menyatakan bahwa rasio efektivitas berpengaruh positif terhadap pertumbuhan ekonomi. Semakin besar pendapatan asli daerah yang diserap maka semakin besar kemampuan pemerintah daerah untuk meningkatkan pertumbuhan ekonomi dan semakin menunjukkan kinerja keuangan yang positif. Jika dikaitkan dengan teori keagenan pemerintah pada daerah pemekaran diharapkan mampu memberikan kinerja yang baik melalui realisasi penerimaan PAD. Karena semakin besar realisasi PAD maka semakin baik dan terlihat bahwa pemerintah daerah telah berusaha dengan baik. Sehingga hipotesis yang diajukan dalam penelitian ini adalah:

H3: Rasio efektivitas berpengaruh positif terhadap pertumbuhan ekonomi daerah hasil pemekaran di Pulau Sumatera.

\section{Hipotesis}

H1

Rasio derajat desentralisasi berpengaruh negatif terhadap pertumbuhan ekonomi daerah hasil pemekaran di Pulau Sumatera

$\mathrm{H} 2$

Rasio ketergantungan keuangan daerah berpengaruh negatif terhadap pertumbuhan ekonomi daerah hasil pem ekaran di Pulau Sumatera

H3

Rasio efektivitas berpengaruh positif terhadap pertumbuhan ekonomi daerah hasil pemekaran di Pulau Sumatera

\section{METODE PENELITIAN}

Populasi penelitian ini adalah seluruh pemerintahan daerah pemekaran di Pulau Sumatera. Penelitian dilakukan secara sensus atas laporan realisasi APBD 80 Kabupaten/Kota hasil pemekaran di Pulau Sumatera tahun 2013-2017, sehingga diperoleh data berjumlah 400. Jenis data dalam penelitian ini adalah data sekunder. Data diperoleh dari dokumen Laporan Realisasi APBD yang diperoleh dari Badan Pemeriksa Keuangan (BPK). Sedangkan data Pertumbuhan Ekonomi yaitu dengan menggunakan data Produk Domestik Regional Bruto (PDRB) diperoleh dari Badan Pusat Statistik (BPS).

Pada penelitian ini daerah pemekaran dibagi menjadi dua bentuk yaitu daerah pemekaran lama dan daerah pemekaran baru. Hal ini dilakukan untuk menyesuaikan kondisi di masing-masing daerah. Rentan waktu untuk penentuan daerah pemekaran lama (DPL) adalah daerah yang diresmikan dari tahun 19902005. Sedangkan daerah pemekaran baru (DPB) adalah daerah yang diresmikan dari tahun 2006-2018. Pengujian hipotesis dalam penelitian ini menggunakan analisis regresi linier berganda dengan menggunakan SPSS (Statistical Procut and Service Solutions) versi 23. Dasar penggunaan linier berganda adalah skema satu variabel dependen (Y) yang berupa pertumbuhan ekonomi yang dihubungkan dengan dua atau lebih variabel independen $(\mathrm{X})$ yang berupa rasio derajat desentralisasi, rasio ketergantungan keuangan daerah, dan rasio efektivitas. Pengujian hipotesis akan dilakukan dengan analisis regresi berganda yang diformulasikan sebagai berikut :

$$
\mathrm{Y}=\alpha+\beta 1 \mathrm{X} 1+\beta 2 \mathrm{X} 2+\beta 3 \mathrm{X3}+\mathrm{e}
$$


Keterangan :

\begin{tabular}{|c|c|}
\hline $\mathrm{Y}$ & $=$ Pertumbuhan Ekonomi \\
\hline $\mathrm{X} 1$ & $=$ Rasio Derajat Desentralisasi \\
\hline $\mathrm{X} 2$ & $=$ Rasio Ketergantungan Keuangan Daerah \\
\hline $\mathrm{X} 3$ & $=$ Rasio Efektivitas \\
\hline$\beta 123$ & $=$ Koefisien regresi \\
\hline & $=$ Konstanta \\
\hline & $=$ Error of estimation \\
\hline
\end{tabular}

\section{ANALISIS DAN PEMBAHASAN}

\section{Deskripsi Sampel Penelitian}

Objek dalam penelitian ini adalah seluruh Kabupaten dan Kota hasil pemekaran di Pulau Sumatera selama periode tahun 2013-2017. Pemilihan sampel dalam penelitian ini ditentukan dengan menggunakan metode Purposive sampling sehingga total sampel akhir sejumlah 80 kabupaten/kota hasil pemekaran daerah di Pulau Sumatera tahun 2013 sampai tahun 2017.

\section{Deskripsi Variabel}

Analisis deskriptif dari data yang diambil untuk penelitian ini adalah dari tahun 2013 sampai dengan tahun 2017 dari 80 kabupaten / kota hasil pemekaran di Pulau Sumatera. Dengan menggunakan data gabungan ( pool) selanjutnya diperoleh sebanyak 5 x $80=400$ data pengamatan. Pada penelitian ini terdapat 61 data yang digunakan sebagai sampel penelitian pada daerah pemekaran lama, dan 19 data pada daerah pemekaran baru. Seiring proses analisis data, ada beberapa data yang dihapus (Outlier). Menurut Ghozali (2016) Outlier adalah kasus atau data yang memiliki karakteristik unik yang terlihat sangat berbeda jauh dari observasi-observasi lainnya dan muncul dalam bentuk nilai ekstrim. Data outlier ini harus dihapus dari pengamatan. Distribusi statistik deskriptif untuk masing-masing variabel terdapat pada tabel berikut :

Tabel 5 Statistik Deskriptif

\begin{tabular}{ccccccccccc}
\hline & \multicolumn{2}{c}{ N } & \multicolumn{2}{c}{ Minimum } & \multicolumn{2}{c}{ Maximum } & \multicolumn{2}{c}{ Mean } & \multicolumn{2}{c}{ Std. Deviation } \\
& DPL & DPB & DPL & DPB & DPL & DPB & DPL & DPB & DPL & DPB \\
\hline \hline RDD & 265 & 88 & 1,61 &, 41 & 15,09 & 8,45 & 6,3023 & 4,0886 & 2,91068 & 1,42702 \\
RKET & 265 & 88 & 72,78 & 75,68 & 101,45 & 97,33 & 90,1216 & 92,1849 & 5,79464 & 4,81657 \\
RE & 265 & 88 & 51,81 & 24,16 & 147,63 & 161,57 & 97,3786 & 91,4752 & 16,50090 & 24,93528 \\
PE & 265 & 88 &, 52 & 2,85 & 8,96 & 8,45 & 4,9294 & 5,2124 & 1,26210 &, 99473 \\
$\begin{array}{c}\text { Valid N } \\
\text { (listwise) }\end{array}$ & 265 & 88 & & & & & & & & \\
\hline \hline
\end{tabular}

Sumber: Data Olahan SPSS 23, 2018

Keterangan : DPL (Daerah Pemekaran Lama), DPB (Daerah Pemekaran Baru), RDD (Rasio Derajat Desentralisasi), RKET (Rasio Ketergantungan), RE (Rasio Efektivitas).

\section{Uji Asumsi Klasik}

\section{Uji Normalitas}

Pada gambar dibawah terlihat P-P plot yang menunjukkan pola distribusi normal, dimana titik-titik menyebar di sekitar garis diagonal dan mengikuti arah garis diagonal. Hal ini mengindikasikan bahwa variabel-variabel dalam model regresi terdistribusi normal. Dengan demikian dapat disimpulkan bahwa model regresipada daerah pemekaran lama telah memenuhi asumsi normalitas. 

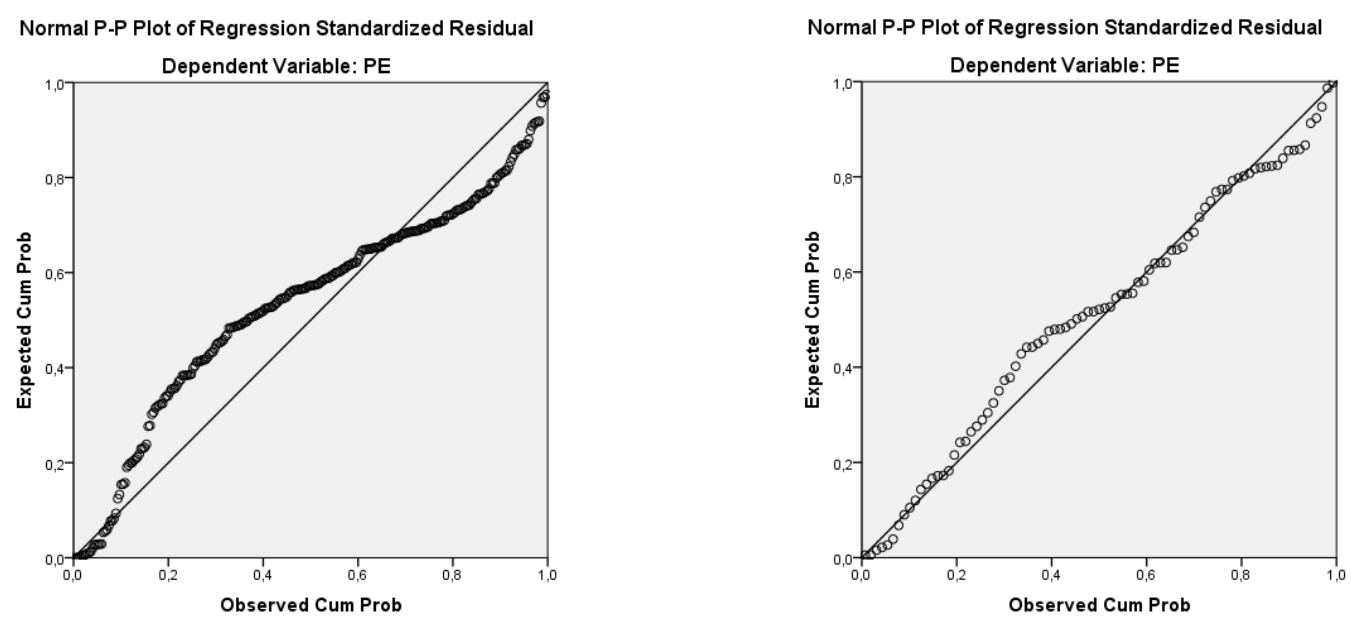

Sumber: Data Olahan SPSS 23, 2018

\section{Uji Multikolinieritas}

Uji multikolinieritas bertujuan untuk menguji apakah dalam model regresi ditemukan adanya korelasi antar variabel independen (Ghozali, 2016). Model regresi yang baik adalah model yang tidak mengalami multikolinieritas. Multikolinieritas dapat dilihat dari nilai Tolerance dan Variance Inflation Factor (VIF) yang apabila memiliki nilai Tolerance $\geq 0,05$ atau sama dengan VIF $\leq 5$ berarti model regresi tersebut terbebas dari multikolinieritas.

Tabel 6 Uji Multikolinieritas

\begin{tabular}{ccccc}
\hline & & \multicolumn{2}{c}{ Collinearity Statistics } & \\
Model & Tolerance & & VIF & \\
& DBL & DPB & DBL & \\
\hline \hline (Constant) & & & & \\
RDD &, 883 &, 952 & 1,132 & 1,051 \\
RKET &, 890 &, 968 & 1,124 & 1,033 \\
RE &, 992 &, 949 & 1,009 & 1,054 \\
\hline \hline
\end{tabular}

\section{Uji Autokorelasi}

Sumber: Data Olahan SPSS 23, 2018

Diketahui bahwa nilai asymp.sig. sebesar ,930 dan ,879 sehingga dapat disimpulkan bahwa residual adalah random atau bebas dari autokorelasi. Karena Asymp.sig (2tailed) lebih dari 0,05.

Tabel 7 Uji Autokorelasi

\begin{tabular}{|c|c|c|}
\hline & \multicolumn{2}{|c|}{ Unstandardized Residual } \\
\hline & DPL & DPB \\
\hline Test Value $^{\mathrm{a}}$ &, $62194^{\mathrm{b}}$ & $3,24908^{b}$ \\
\hline Cases $<$ Test Value & 263 & 87 \\
\hline Cases $>=$ Test Value & 1 & 1 \\
\hline Total Cases & 264 & 88 \\
\hline Number of Runs & 3 & 3 \\
\hline $\mathrm{Z}$ & 087 &, 152 \\
\hline Asymp. Sig. (2-tailed) & ,930 & 879 \\
\hline
\end{tabular}

Sumber: Data Olahan SPSS 23, 2018

\section{Uji Heterokedastisitas}

Pada gambar dibawah dapat dilihat persebaran titik scatterplots yang tidak membentuk pola yang jelas dan menyebar di atas dan di bawah angka 0 pada sumbu Y. Dengan demikian dapat disimpulkan 
bahwa model regresi Rasio Derajat Desentralisasi (RDD), Rasio ketergantungan keuangan (RKET), dan Rasio Efektivitas (RE) tidak mengalami heteroskedastisitas atau memiliki variance dari residual satu pengamatan ke pengamatan lain yang tetap.
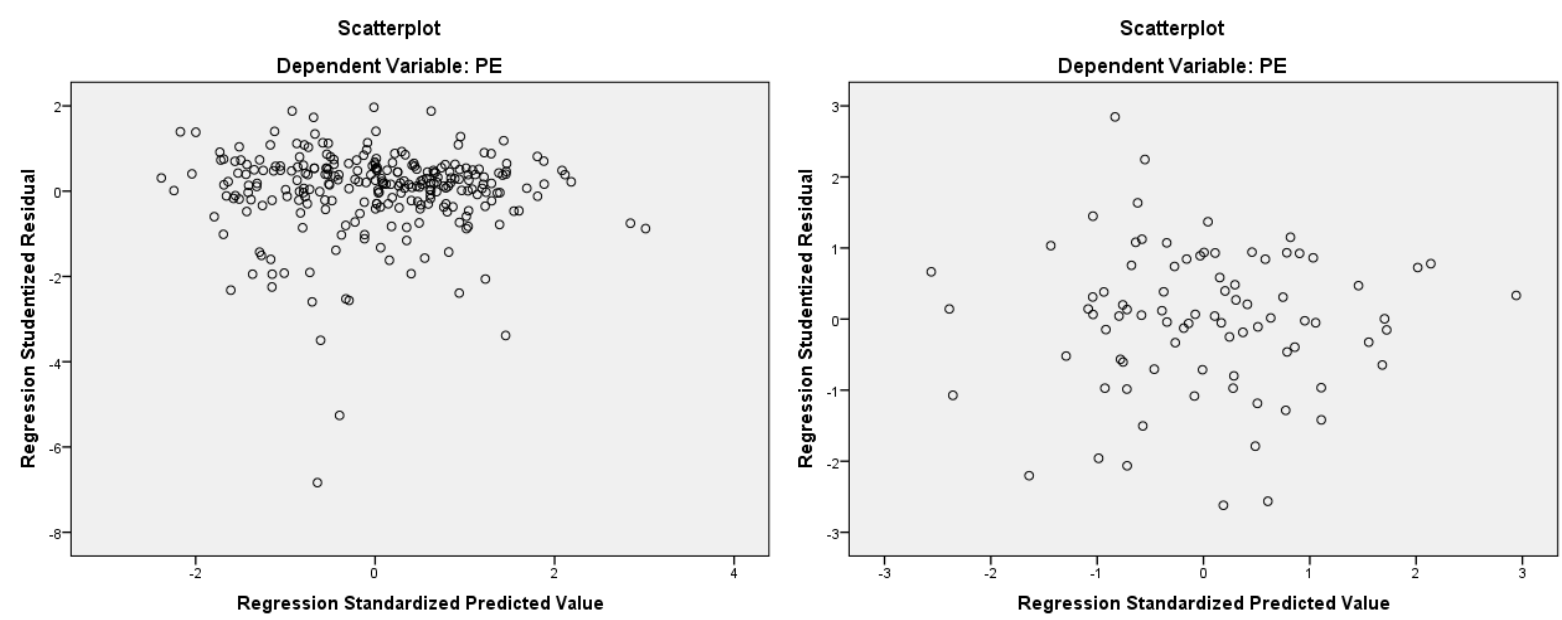

Sumber: Data Olahan SPSS 23, 2018

\section{Pengujian Hipotesis}

Tabel dibawah ini memberikan informasi dimana hasil pengujian koefisien determinasi diketahui Adjusted $R$ Square sebesar 0,187 atau 18,7\% (DPL) dan 0,175 atau 17,5\% (DPB). Hasil tersebut menunjukkan bahwa kemampuan ketiga variabel independen yang terdiri dari rasio derajat desentralisasi, rasio ketergantungan keuangan, dan rasio efektivitas dalam menjelaskan variabel dependen masih sangat terbatas. Sisanya dipengaruhi oleh variabel lainyang tidak dapat dijelaskan oleh variabel independen yang terdapat dalam penelitian ini.

Tabel 8 Uji Koefisien Determinasi $\mathbf{R}^{2}$

\begin{tabular}{|c|c|c|c|c|}
\hline \multirow{3}{*}{ Model } & \multicolumn{2}{|c|}{ Model Summary } & & \\
\hline & \multicolumn{2}{|c|}{ R Square } & \multicolumn{2}{|c|}{ Adjusted R Square } \\
\hline & DPL & DPB & DPL & DPB \\
\hline 1 & ,206 & ,221 &, 187 & ,175 \\
\hline
\end{tabular}

Sumber: Data Olahan SPSS 23, 2018

Tabel dibawah memberikan informasi dimana nilai signifikansi sebesar ,004 dan ,049. Nilai signifikansi tersebut kurang dari nilai $\alpha$ yaitu 0,05 yang artinya hipotesis ditolak (koefisien regresi signifikan) untuk memprediksi pertumbuhan ekonomi atau dapat dikatakan bahwa semua variabel independen dalam penelitian ini yang terdiri dari Rasio Derajat Desentralisasi, Rasio Ketergantungan Keuangan, dan Rasio Efektivitas mempunyai pengaruh terhadap variabel dependen (Pertumbuhan Ekonomi).

Tabel 9 Uji Signifikansi Simultan (Uji Statistik F)

\begin{tabular}{|c|c|c|c|c|c|}
\hline \multicolumn{6}{|c|}{ ANOVA $^{a}$} \\
\hline & \multirow{2}{*}{ Model } & \multicolumn{2}{|c|}{$\mathrm{F}$} & \multicolumn{2}{|c|}{ Sig. } \\
\hline & & DPL & DPB & DPL & $\mathrm{DPB}$ \\
\hline & Regression & 4,497 & 2,594 &, $004^{\mathrm{b}}$ &, $049^{b}$ \\
\hline \multirow[t]{2}{*}{1} & Residual & & & & \\
\hline & Total & & & & \\
\hline
\end{tabular}


Coefficients $^{\mathrm{a}}$

\begin{tabular}{|c|c|c|c|c|c|c|c|c|c|c|}
\hline \multirow{4}{*}{ Model } & \multirow{2}{*}{\multicolumn{4}{|c|}{ Unstandardized Coefficients }} & \multirow{3}{*}{\multicolumn{2}{|c|}{$\begin{array}{c}\text { Standardized } \\
\text { Coefficients } \\
\text { Beta }\end{array}$}} & \multirow{3}{*}{\multicolumn{2}{|c|}{$\mathrm{T}$}} & \multirow{3}{*}{\multicolumn{2}{|c|}{ Sig. }} \\
\hline & & & & & & & & & & \\
\hline & \multicolumn{2}{|c|}{ B } & \multicolumn{2}{|c|}{ Std. Error } & & & & & & \\
\hline & DPL & DPB & DPL & DPB & DPL & DPB & DPL & DPB & DPL & DPB \\
\hline (Constant) & 4,523 & 7,515 & ,635 & 2,077 & & & , 199 & 3,618 &, 842 &, 001 \\
\hline RDD &,- 398 &,- 154 & ,109 &, 074 & $-1,107$ &,- 228 & $-2,838$ & $-2,074$ &, 005 &, 041 \\
\hline RKET & ,246 &,- 024 &, 068 & ,022 & 1,095 &,- 116 & ,264 & $-1,064$ & ,792 & ,291 \\
\hline RE &, 010 &, 005 & ,006 & ,004 & 093 & ,142 & 2,195 & 1,283 & 029 & ,203 \\
\hline
\end{tabular}

Sumber: Data Olahan SPSS 23, 2018

Berdasarkan hasil statistik dapat disimpulkan model regresi berganda pada daerah pemekaran dengan persamaan sebagai berikut:

a. Daerah Pemekaran Lama

$\mathrm{Y}=4,523+(-0,398 \mathrm{RDD})+0,246 \mathrm{RKET}+0,010 \mathrm{RE}$

b. Daerah Pemekaran Baru

$\mathrm{Y}=7,515+(-0,154$ RDD $)+(-0,024$ RKET $)+0,005$ RE

Dari hasil statistik diatas juga didapatkan hasil pengujian hipotesis sebagai berikut:

\begin{tabular}{clcc}
\hline & \multicolumn{1}{c}{ Hipotesis } & Hasil & DPL \\
\hline \hline H1 & $\begin{array}{l}\text { Rasio Derajat Desentralisasi berpengaruh negatif terhadap } \\
\text { Pertumbuhan Ekonomi }\end{array}$ & Terdukung & Terdukung \\
H2 & $\begin{array}{l}\text { Rasio Ketergantungan keuangan berpengaruh negatif } \\
\text { terhadap Pertumbuhan Ekonomi } \\
\text { Rasio Efektivitas berpengaruh positif terhadap Pertumbuhan } \\
\text { Ekonomi }\end{array}$ & Tidak Terdukung & Tidak Terdukung \\
H3 & Terdukung & Tidak Terdukung \\
\hline \hline
\end{tabular}

Pembahasan

Dari hasil analisis regresi linier berganda variabel rasio derajat desentralisasi yang dihitung dengan rumus Pendapatan Asli Daerah (PAD) dibagi total pendapatan daerah mempunyai pengaruh yang negatif dan signifikan terhadap variabel pertumbuhan ekonomi pada daerah pemekeran lama maupun didaerah pemekaran baru. Diketahui bahwa penyelenggaraan desentralisasi (RDD) belum terlaksana dengan baik didaerah pemekaran lama maupun daerah pemekaran baru. Hal ini terlihat dari rata-rata penerimaan PAD yang terlalu kecil dan masuk kedalam kategori sangat kurang dibandingan dengan total pendapatan daerah. Faktor pertama mengapa hal ini dapat terjadi adalah PAD yang ditargetkan terlalu kecil. Lalu adanya desentralisasi membuat pemerintah pusat sulit melakukan kontrol pada sub-nasional (Pemda). Berdasarkan penelitian yang dilakukan oleh Prud'homme (1995) salah satu penyebab kegagalan desentralisasi fiskal adalah korupsi korupsi karena umumnya politisi atau birokrat lokal lebih rentan karena mudah diakses oleh kelompok yang memiliki kepentingan, jika korupsi bisa dikurangi atau dihilangkan maka akan tercipta efesiensi alokasi dan mendorong pertumbuhan ekonomi. Dari segi masyarakat terlihat bahwa partisipasi masyarakat masih rendah dalam hal penerimaan PAD. Faktor terakhir adalah Mendagri mengatakan bahwa masih ada daerah yang ingin dimekarkan, namun sampai tiga tahun belum bisa menentukan pusat kotanya. Ada pula yang menggelembungkan jumlah penduduk meski kecamatannya hanya ada lima. Dari pernyataan tersebut dapat dikatakan bahwa sebenarnya daerah tersebut belum siap untuk dimekarkan. Jadi 
semakin banyak terjadinya penyelanggaraa desentralisasi (pemekaran daerah) maka akan semakin menurunkan angka pertumbuhan ekonomi

1. Dari hasil analisis regresi linier berganda variabel rasio ketergantungan keuangan daerah yang dihitung dengan rumus pendapatan transfer dibagi total pendapatan daerah tidak berpengaruh terhadap pertumbuhan ekonomi pada daerah pemekaran lama dan daerah pemekaran baru . Hasil tersebut menjelaskan bahwa hipotesis kedua tentang rasio ketergantungan daerah berpengaruh negatif terhadap pertumbuhan ekonomi tidak terdukung atau tidak diterima. Pada hasil uji signifikansi parameter individual (Uji Statistik t) daerah pemekaran lama diketahui bahwa rasio ketergantungan tidak berpengaruh terhadap pertumbuhan ekonomi. Kurangnya kemampuan untuk mengelola dana transfer secara transparan dan akuntabel dapat melatarbelakangi mengapa hal ini dapat terjadi. Selanjutnya Kharisma (2013) menyatakan apabila dana perimbangan yang mengalir ke daerah tidak dibarengi oleh proses perencanaan yang baik dengan prinsip partisipatif dari masyarakat dan tidak diimbangi oleh kemampuan pemerintah daerah dalam mengelola keuangan secara transparan dan akuntabel maka dana yang besar tersebut tidak akan mempunyai dampak yang cukup berarti bagi perekonomian daerah tersebut karena hanya dinikmati oleh beberapa orang saja.

2. Dari hasil analisis regresi linier berganda variabel rasio efektivitas yang dihitung dengan rumus realisasi penerimaan PAD dibagi anggaran penerimaan PAD berpengaruh positif terhadap pertumbuhan ekonomi pada daerah pemekaran lama. Dari hasil tersebut menjelaskan bahwa hipotesis ketiga tentang rasio efektivitas berpengaruh positif terhadap pertumbuhan ekonomi darah pemekaran lama terdukung atau diterima. Nilai koefisien rasio efektivitas sebesar 0,010. Artinya adalah setiap adanya kenaikan rasio efektivitas menunjukkan nilai positif sebesar 0,010 pada kabupaten/kota hasil pemekaran daerah lama di Sumatera. Artinya, setiap kenaikan rasio efektivitas sebesar 1\% maka akan terjadi kenaikan pada pertumbuhan ekonomi sebesar 0,010\%. Penelitian yang dilakukan oleh Suwandi (2015) dimana rasio efektivitas berpengaruh positif terhadap pertumbuhan ekonomi mengindikasikan bahwa penggalian potensi-potensi penerimaan pendapatan asli daerah (PAD) dapat dikatakan sudah baik, walaupun begitu penetapan target penerimaan pendapatan asli daerah (PAD) terbilang masih kecil, karena penerimaan pendapatan asli daerah (PAD) belum sebanding atau masih terlalu kecil apabila dibandingkan dengan dana transfer (dana perimbangan) dari pemerintah pusat. Berbeda dengan daerah pemekaran baru, rasio efektivitas tidak berpengaruh terhadap pertumbuhan ekonomi. Salah satu alasan yang kuat mengapa hal tersebut dapat terjadi ialah kurangnya pelayanan publik yang disediakan oleh pemerintah daerah pemekaran baru bagi masyarakat.

\section{E. SIMPULAN DAN SARAN}

Dari hasil analisa dan pembahasan mengenai pengaruh kinerja keuangan pemerintah daerah terhadap Pertumbuhan ekonomi (studi pada daerah pemekaran di Pulau Sumatera) dapat disimpulkan sebagai berikut : (1). Rasio derajat desentralisasi yang dihitung dengan rumus Pendapatan Asli Daerah (PAD) dibagi total pendapatan daerah mempunyai pengaruh yang negatif dan signifikan terhadap variabel pertumbuhan ekonomi pada daerah pemekeran lama dan daerah pemekaran baru. Artinya kontribusi PAD masih relatif kecil dibandingan dengan total pendapatan daerah. dapat dikatakan bahwa penyelenggaraan desentralisasi di daerah pemekaran lama dan daerah pemekaran baru belum terlaksana dengan baik. Salah satu faktor yang menyebabkan hal tersebut terjadi adalah rendahnya partisipasi masyarakat terhadap kontribusi PAD. (2). Dari hasil analisis regresi linier berganda variabel rasio ketergantungan keuangan daerah yang dihitung dengan rumus pendapatan transfer dibagi total pendapatan daerah tidak berpengaruh terhadap pertumbuhan ekonomi pada daerah pemekaran lama dan daerah pemekaran baru. Hasil tersebut menjelaskan bahwa hipotesis kedua tentang rasio ketergantungan daerah berpengaruh negatif terhadap pertumbuhan ekonomi tidak terdukung atau tidak diterima. Artinya dana transfer yang diberikan pemerintah pusat dan provinsi belum digunakan dengan tepat sasaran. Faktor yang dapat menyebabkan hal ini terjadi adalah kurangnya kemampuan pemerintah daerah untuk mengelola dana transfer secara transparan dan akuntabel. 
Faktor lainnya adalah dana transfer yang diberikan tidak dibarengi proses perencanaan yang baik. (3). Dari hasil analisis regresi linier berganda variabel rasio efektivitas yang dihitung dengan rumus realisasi penerimaan PAD dibagi anggaran penerimaan PAD berpengaruh positif terhadap pertumbuhan ekonomi pada daerah pemekaran lama. Dari hasil tersebut menjelaskan bahwa hipotesis ketiga tentang rasio efektivitas berpengaruh positif terhadap pertumbuhan ekonomi terdukung atau diterima. Artinya kinerja pemerintah untuk menyerap PAD sehingga melebihi target penerimaan PAD sudah baik dan berpengaruh positif terhadap pertumbuhan ekonomi. Namun, pada daerah pemekaran baru rasio efektivitas tidak berpengaruh terhadap pertumbuhan ekonomi. Salah satu faktor yang menyebabkan hal ini terjadi adalah PAD yang ditargetkan masih relatif kecil.

Penelitian ini memiliki beberapa keterbatasan, yaitu: (1). Data yang digunakan adalah data sekunder yang diambil dari publikasi anggaranpemerintah daerah, data PDRB, dan laporan keuangan pemerintah daerah pemekaran. Setelah dilakukan olah data ada data yang nilainya terlalu ekstrem, sehingga ada beberapa data yang dihapus (outlier). (2). Kinerja keuangan yang dinilai rasio keuangan pada penelitian ini hanya menggunakan rasio derajat desentralisasi, rasio ketergantungan keuangan, dan rasio efektivitas. (3). Dari hasil perhitungan koefisien determinasi (adjusted R2) pada bab sebelumnya, ketiga model regresi hanya memiliki nilai adjusted $\mathrm{R} 2$ yang relatif kecil. Hal ini berarti kemampuan variabel independen dalam menjelaskan variasi-variabel dependen relatif kecil.

Untuk penelitian selanjutnya disarankan agar: (1). Menggunakan data primer melalui kuesioner bagi aparatur pemerintahan daerah agar data yang digunakan lebih lengkap. (2). Menambah rentang waktu penelitian dengan mengambil periode yang lebih panjang. (3). Menggunakan sampel penelitian yang lebih banyak dari penelitian ini agar mendapatkan hasil yang komprehensif. (4). Menambah rasio keuangan lainnya agar mendapatkan hasil yang komprehensif.

Dengan mempertimbangkan hasil analisis, kesimpulan, keterbatasan, dan saran yang telah dikemukakan di atas, maka implikasi yang dapat diberikan untuk pemerintah adalah sebagai berikut:

1. Berdasarkan hasil statistik deskriptif dapat diambil kesimpulan bahwa penyelenggaraan desentralisasi masih belum baik. Melalui skala interval pada rasio derajat desentralisasi diketahui bahwa kontribusi PAD terhadap total pendapatan daerah masuk kedalam kategori sangat kurang. Hal ini terjadi baik pada daerah pemekaran lama dan baru. Dengan demikian, hasil penelitian ini dapat digunakan sebagai bahan evaluasi bagi pemerintah daerah. Agar selanjutnya dapat mendorong masyarakat untuk turut serta membangun daerahnya masing-masing melalui kontribusi PAD yang terus ditingkatkan. Langkah yang dapat diambil untuk menggali potensi PAD masing-masing daerah adalah melalui sektor pariwisata. Sebaiknya pemerintah daerah jeli melihat peluang-peluang pariwisata yang dapat menarik wisatawan untuk datang ke daerah tersebut.

2. Berdasarkan hasil statistik deskriptif dapat ditarik kesimpulan bahwa ketergantungan keuangan daerah pemekaran masih sangat tinggi terhadap dana transfer yang diberikan oleh pemerintah pusat ataupun provinsi. hal ini terjadi baik pada daerah pemekaran lama maupun daerah pemekaran baru. Melalui hasil penelitian ini diharapkan menjadi bahan evaluasi bagi pemerintah daerah untuk dapat mengelola dana transfer dengan bijak. Sebaiknya pemberian dana transfer ini dapat dibarengi dengan proses perencanaan yang baik agar dapat membantu pemerintah daerah mensejahterakan masyarakat. Misalnya, dana transfer yang memang diberikan oleh pemerintah pusat maupun pemerintah daerah digunakan bagi pendidikan dan kesehatan tidak boleh diganggu gugat oleh pemerintah daerah dan terus dipantau pelaksanannya. Sehingga dana transfer yang digunakan digunakan tepat sasaran.

3. Berdasarkan hasil statistik deskriptif dikaetahui bahwa keefektifikan kinerja pemerintah daerah pemekaran lama berpengaruh positif terhadap pertumbuhan ekonomi. Hal ini menunjukkan bahwa pemerintah daerah pemekaran lama telah berhasil menggali potensi PAD masing-masing daerah. Berbeda dengan daerah pemekaran baru, realisasi penerimaan PAD tidak berpengaruh terhadap pertumbuhan ekonomi. Salah satu penyebabnya adalah kecilnya anggaran penerimaan PAD yang ditetapkan. Dengan demikian, hasil penelitian ini dapat digunakan sebagai bahan evaluasi bagi 
pemerintah daerah pemekaran untuk terus mengoptimalkan penerimaan PAD. Dimana hal tersebut dapat dilakukan dengan terus menggali potensi PAD dan penggunaan PAD yang tepat sasaran demi terciptanya kesejahteraan masyarakat melalui pertumbuhan ekonomi yang baik. Sebaiknya pemerintah daerah meningkatkan pelayanan publik bagi masyarakat. Misalnya, pemerintah daerah dapat mengadakan pembayaran pajak kendaraan bermotor keliling bagi daerah-daerah yang jauh dari kantor samsat. Sehingga masyarakat yang tadinya enggan membayar pajak kendaraan bermotor karena jarak yang jauh akan mendapatkan peluang membayar dengan cara yang dekat dan mudah.

\section{REFERENSI}

Arsyad, Lincolin. 1999. Pengantar Perencanaan dan Pembangunan Ekonomi Daerah. Edisi Pertama. Yogyakarta: BPFE.

Astuti, Wuku. 2015. Analisis pengaruh kinerja keuangan terhadap pertumbuhan ekonomi dan dampaknya terhadap pengangguran dan kemiskinan (studi pada kabupaten dan kota di pulau jawa periode 2007-2011). Jurnal EBBANK Vol. 6 No. IUniversitas Widya Mataram Yogyakarta.

Badan Litbang Depdagri RI dan FISIPOL-UGM. 1991. Pengukuran Kemampuan II Dalam Rangka Otonomi Daerah Yang Nyata Dan Bertanggung Jawab. Jakarta.

Badan Pusat Statistik. 2016. "Laju Pertumbuhan Ekonomi Kabupaten/Kota Di Sumatera 2013-2017”. Jakarta: Badan Pusat Statistik. (Diakses 21 Mei 2018).

Berliani, Kartika. 2016. Pengaruh kinerja keuangan terhadap pertumbuhan ekonomi dan implikasinya terhadap kesejahteraan masyarakat kabupaten majalengka. Jurnal Indonesia Membangun ISSN: 1412-6907 Vol. 2, No. 1. Mei-Agustus 2016.

Ghozali, Imam. 2016. Aplikasi Analisis Multivariete Dengan Program IBM SPSS 23 (Edisi 8). Cetakan ke VIII. Semarang: Badan Penerbit Universitas Diponegoro.

Halim, Abdul. 2007. Akuntansi Sektor Publik: Akuntansi Keuangan Daerah. Jakarta: Salemba Empat.

Kharisma, Bayu. 2013. Desentralisasifiskal dan pertumbuhan ekonomi: sebelum dan sesudah era desentralisasi fiskal di indonesia. Jurnal Ekonomi dan Studi Pembangunan Vol 14, No 2, Fakultas Ekonomi, Universitas Padjajaran.

Kuncoro, Mudrajad. 2014. Otonomi Daerah Menuju Era Baru Pembangunan Daerah Edisi 3. Yogyakarta: Erlangga. Mahmudi. 2010. Manajemen Keuangan Daerah. Jakarta: Erlangga.

Mardiasmo. 2002. Otonomi dan Manajemen Keuangan Daerah. Yogyakarta: Andi.Pradiatmi, Istia Nur dan Hardiyanto Wibowo. 2017. Pengaruh kinerja keuangan dan belanja modal terhadap pertumbuhan ekonomi pada kabupaten/kota di jawa tengah. Jurnal Reviu Akuntansi dan Keuangan Vol 5, No 2 Universitas Muhammadiyah Malang.

Prihastuti, dkk, Asepma Hygi; Taufeni Prihastuti, dkk; Restu Agusti. 2015. Pengaruh kinerja keuangan terhadap alokasi belanja modal dan pertumbuhan ekonomi di kabupaten/kota riau. Jurnal Sorot, Vol 10, No.2, Lembaga Penelitian dan Pengabdian kepada Masyarakat Universitas Riau.

Prud'homme, Remy.1995.The dangers of decentralization.The World Bank Research Observer vol. 10 no. 2.

Rosdyana, Dewi, E. Susy Suhendra, Rowland Bismark Fernando Pasaribu. 2015. Pengaruhdesentralisasi fiskal terhadap pertumbuhan ekonomi daerah danketimpangan pendapatan di pulau jawa tahun 2009-2013. Prosiding PESAT (Psikologi, Ekonomi, Sastra, Arsitektur \& Sipil) Vol. 6, Oktober 2015 Universitas Gunadarma. ISSN: 1858-2559.

Sari, Greydi Normala. 2016. Pengaruh kinerja keuangan terhadap pertumbuhan ekonomiperkotaan di sulawesi utara tahun 2004-2014. Jurnal Pembangunan Ekonomi dan Keuangan Daerah Vol 18 No 2 tahun 2016 Magister Ilmu Ekonomi Universitas Sam Ratulangi, Manado.

Sularso, Havid dan Yanuar E. Restianto. 2011. Pengaruh kinerja keuangan terhadap alokasi belanja modal dan pertumbuhan ekonomi kabupaten kota di jawa tengah. Media Akuntansi Riset, Vol 1 No 2 Agustus 2011.

Wachid, Abdul. 2014. Analisis kinerja keuangan serta kemampuan keuangan pemerintah daerah dalam pelaksanaan otonomi daerah. Jurnal Administrasi Publik (JAP), Vol 2, No 2.

Zurkarnain, M.S. 2015. Pengaruh rasio keuangan daerah terhadap pertumbuhan ekonomi daerah melalui alokasi belanja modal di kabupaten dan kota provinsi aceh. Jurnal Manajemen Sains, 3 (4), 423-435.

Undang-undang Republik Indonesia Nomor 23 Tahun 2014 tentang Pemerintah Daerah Undang-undang Republik Indonesia Nomor 32 Tahun 2004 Tentang Pemerintah Daerah. 